\title{
Teaching Applied Geophysics at RTU: the Basics for a Fast, Green, Inexpensive Subground Investigation Method
}

\author{
Francesco Romagnoli, Institute of Energy Systems and Environment, Riga Technical University, \\ Dagnija Blumberga, Institute of Energy Systems and Environment, Riga Technical University
}

\begin{abstract}
Geophysical methods are applied to determine a spatial model of the underground, to locate fault zones, to investigate the regional ground-water system, or to derive lithological parameters. In other words, applied geophysics provides the distribution of physical parameters of the subsurface through surveys at the earth's surface without destroying soil formations. In Latvia there are few expert companies of geophysics surveys.

Thus, it is important that environmental experts have knowledge in this, and that Latvia, as a country, has access to international expertise.

During the study introduced hereto we compared the geophysics course in the Riga Technical University (RTU) with similar courses in eight European universities and one Latvian university, gathering information through websites and/or personal contacts. We collected information about the duration of the courses, learning objectives, topics, teaching methods, credit points etc. As a result, proposals on how to improve the course in RTU were elaborated.
\end{abstract}

Keywords - Geophysics, geophysical methods, bachelor, master, environmental engineering.

\section{INTRODUCTION}

The principal sources of energy and the vast majority of raw materials required for the construction, manufacturing, and chemical industries are found in the outer layers of our planet. In many areas, vital water supplies are stored in the shallow underground and it is in the upper few tens of metres where household and industrial wastes are commonly buried. Knowledge of the shallow underground is important for the planning of major buildings and civil engineering projects and for predicting the consequences of natural catastrophes.

To meet the growing needs of the world's expanding population for natural resources, to resolve problems created by our misuse of the land, to provide critical data to architects and civil engineers, and to forecast the effects of natural disasters, it is necessary for us acquire even more detailed knowledge of the structure, composition, and condition of the outer skin of the Earth [1].

\section{APPLIED GEOPHYSICS: SHORT OVERVIEW}

The term "geophysics" is often used in a restricted sense to denote the physics applied to the study of the "solid earth". Solid earth geophysics is traditionally divided into two main fields of study: global geophysics and exploration geophysics whereby the first involves studies of large-scale problems relating to the earth's gross structure and dynamic behavior, and the second deals specially with applications of geophysical techniques to problems of oil/gas water, and mineral exploration (applied geophysics) [2].

Geophysical exploration is rapidly expanded over the past 50 years and has helped in regard to the increasing needs for raw materials and energy resources required by modern civilization. Even this aspect has been (and still is) related to oil exploitation and geophysics applications have created new tasks in relation to environmental protection [2].

The current environmental problems can include location of buried hazardous waste material, protection of soil and groundwater from contamination, shallow contaminant plumes escaping from poorly conceived landfills and tracing, planning of new, safe and secure disposal sites dumping of nuclear, industrial, and domestic waste. In addition, the applied geophysics are providing a good tool for various engineering/geotechnical problems in connection to mining, oil and gas production, nuclear power installations, earthworks and heavy construction.

In the context of the integrity and safety of critical manmade structures - such as nuclear waste disposal site, dams and subways - the environmental and engineering aspects cover a role of great importance and central aims.

Most targets of environmental and engineering interest are at shallow depths. Very often, the near surface source that are treated as "noise" in conventional exploration surveys, now become the main target of investigation and for their accurate location and characterization it is usually necessary to lay-out a closely spaced grid of observation points.

The main target for the subsurface geophysics investigations is detecting a discontinuity where one portion of the subground is sufficiently different from another in terms of physical properties.

In other words, geophysical techniques measure physical phenomena such as gravity, magnetism, elastic waves, electricity, and electromagnetic waves.

These physical property changes are related, among others, to density, magnetic susceptibility, elasticity, spontaneous polarization, electric resistivity and conductivity, dielectric permittivity, radioactivity, and thermal conductivity.

The right choice of a particularly geophysical techniques or a combination of techniques depends very much on the relative contrasts of the physical contrast among the target structure and the surroundings, depth extent of a target, and the nature properties as possible by various geophysical 
methods enable a countercheck of results and enhance the reliability of interpretation.

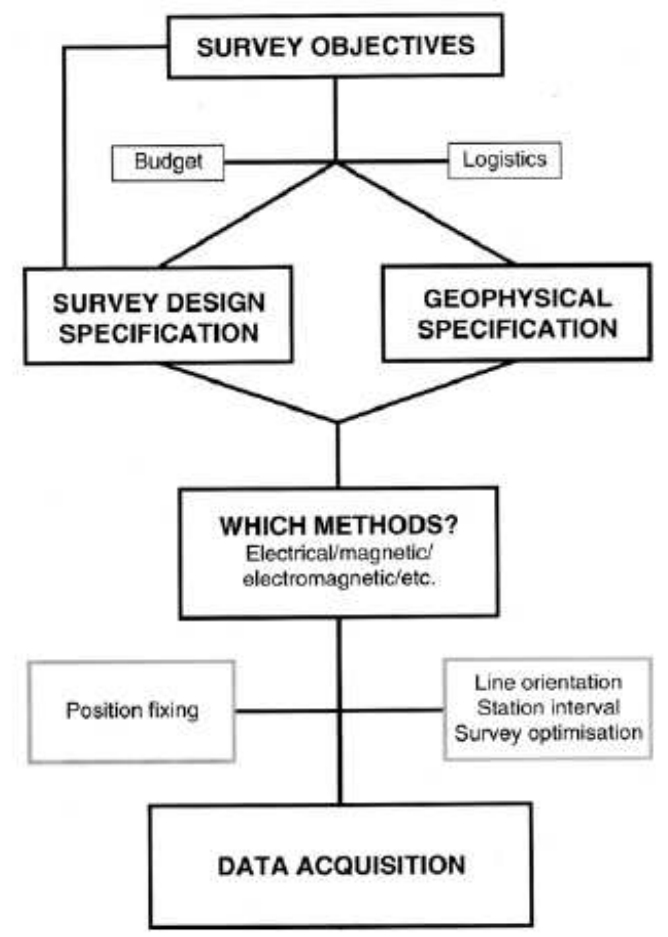

Fig. 1. Survey planning scheme [3]. and the interpretation are both related to specific choices depending on:

- preliminary information of the extension and type of the geophysical anomaly to be detected in relation to the available budget and logistics (survey objectives),

- local condition in the survey site, e.g. site geomorphological conditions, local terrain condition, restrictions (survey design specifications),

- problems directly connected with the local geophysical condition, e.g. presence of surrounding noises to be removed during the elaboration of the data,

- choice of the best geophysical method (or combination of methods),

- best survey applicable practice (e.g. survey position fixing, line orientation, station interval, survey optimization).

Table 1 shows an indicative implementation of a geophysical method depending on the type of situations that need to be investigated.

As can be seen in Picture 2 the resistivity methods are one of the best suitable surveys in relation to general hydrogeolocical investigations and the mapping of leakage of a contamination plumes.

As has been reported in the scheme of Figure 1, the cost factor is also an important criterion in choosing which geophysical method to use for a given problem. The cost estimate of a selected technique in a survey area depends on the local terrain conditions, size of the area, grid spacing and number of survey points, instruments to be employed, required precision, depth penetration and detail of interpretation.

Figure 1 summarizes the importance of survey planning, as can be seen in the main factors that affect the data acquisition

TABLE I

GEOPHYSICAL METHODS: TECHNIQUES AND TARGETS

\begin{tabular}{|c|c|c|c|c|c|c|c|c|c|c|c|}
\hline Geophysical Method & $\begin{array}{l}\text { Dependent physical } \\
\text { property }\end{array}$ & 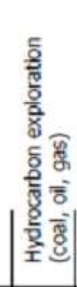 & 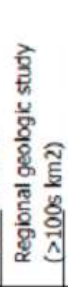 & 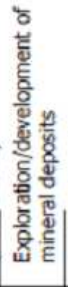 & 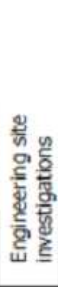 & 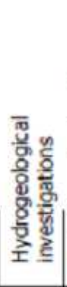 & 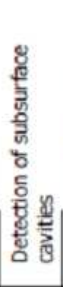 & 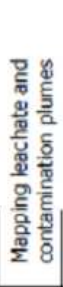 & 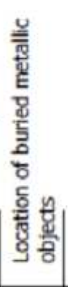 & 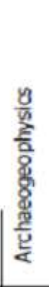 & 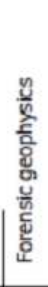 \\
\hline Gravity & Density & P & $\mathbf{P}$ & s & s & s & s & & & s & \\
\hline Magnetic & Susceptibility & $\mathbf{p}$ & $\mathbf{p}$ & $\mathbf{p}$ & s & & m & & $\mathbf{p}$ & $\mathbf{p}$ & \\
\hline Seismic refraction & Elastic moduli, density & $\mathbf{P}$ & p & $\mathrm{m}$ & $\mathbf{P}$ & s & s & & & & \\
\hline Seismic reflection & Elastic moduli, density & $\mathbf{p}$ & $\mathbf{p}$ & $\mathrm{m}$ & s & s & $\mathrm{m}$ & & & & \\
\hline Resistivity & Resistivity & $\mathrm{m}$ & m & $\mathbf{P}$ & $\mathbf{P}$ & $\mathbf{p}$ & $\mathbf{P}$ & $\mathbf{p}$ & s & $\mathbf{p}$ & $\mathrm{m}$ \\
\hline Spontaneous potential & Potential differences & & & $\mathbf{p}$ & $\mathrm{m}$ & $\mathbf{p}$ & $\mathrm{m}$ & $\mathrm{m}$ & $\mathrm{m}$ & & \\
\hline Induced polarization & Resistivity, capacitance & $\mathrm{m}$ & $\mathrm{m}$ & $\mathbf{p}$ & $\mathrm{m}$ & s & $\mathrm{m}$ & $\mathrm{m}$ & $\mathrm{m}$ & $\mathrm{m}$ & $\mathrm{m}$ \\
\hline Electromagnetic (EM) & Conductance, inductance & s & $\mathbf{p}$ & $\mathbf{p}$ & $\mathbf{p}$ & $\mathbf{p}$ & $\mathbf{p}$ & $\mathbf{p}$ & $\mathbf{p}$ & $\mathbf{p}$ & $\mathrm{m}$ \\
\hline EM - VLF & Conductance, inductance & m & m & p & m & s & s & s & m & m & \\
\hline $\begin{array}{l}\text { EM - Ground penetrating } \\
\text { radar }\end{array}$ & Permitivity, conductivity & & & $\mathrm{m}$ & $\mathbf{p}$ & $\mathbf{p}$ & $\mathbf{p}$ & s & $\mathbf{p}$ & p & $\mathbf{p}$ \\
\hline Magneto-telluric & Resistivity & s & $\mathbf{P}$ & $\mathbf{P}$ & m & $\mathrm{m}$ & & & & & \\
\hline
\end{tabular}

$P=$ primary method; $s=$ secondary; $m=$ maybe sometimes 
Judicious application of geophysical techniques to geotechnical investigations can result in significant cost savings. These savings apply to the cost of the investigation, by substituting more expensive investigative methods, and to the cost of the structure by supplying critical geotechnical data. The cost estimate of a selected technique in a survey area depend on several parameters (e.g. local terrain condition, size of area, grid spacing and number of survey points, instruments, required precision, depth penetration) and as a result of these parameters, the final cost can vary. As a simple cost comparison among geophysical survey and classical geotechnical investigation (e.g. core drilling, percussion probing with core destruction) the study of Vogelsang (1995) [4] is reported where the geophysical costs for the survey vary among 0.8 US\$ per line meter (self-potential methods) and 12.0 US\$ per line meter (seismic reflection). By way of comparison, core drilling at the survey site was offered at 150 US\$ per line meter and percussion probing at 20 US\$ per line meter.

Generally and as a rule, geophysical survey costs are much lower than the drilling costs. However despite those advantages, geophysics will never entirely replace drilling because of inherent ambiguities in the interpretation of the geophysical results. In fact, geophysical testing provides an indirect measurement of geologic conditions that should always be substantiated with direct observation. The use of geophysics in conjunction with drilling can reduce costs by focusing drilling activities through initial geophysical investigation [5].

\section{APPLIED GEOPHYSICS: THE METHODS}

The geophysical methods investigate the shallow features of the Earth's crust that vary in accordance with the physical properties of the rocks and grounds are under investigation. On the one hand are the static methods in which the distortions of a static physical field are detected and measured accurately in order to delineate the features producing them (e.g. magnetic methods, gravity methods). There are also dynamic methods in which signals are sent into the ground, returning signals are detected, and their strengths and times of arrival are measured at suitable points (e.g. resistivity methods, electromagnetic methods). In the dynamic methods, the dimension of time always appears, in the appropriate field equations, directly as the time of wave arrival as in the seismic method, or indirectly as the frequency of phase difference as in the electromagnetic method.

Seismic methods (see Figure 2) are based on the measuring of an elastic wave (also: seismic, shockwave, or acoustic wave) travelling through the sub-surface. The wave is reflected or refracted on boundaries characterized by different densities and/or deformation properties. Seismic methods can nearly always be used to determine the internal structure of materials in a slope. Sometimes logistics and practical problems as to how and where geophones and sources can be placed, may make the method impractical. Refraction seismic studies have been the standard tool for geotechnical work for years [6].

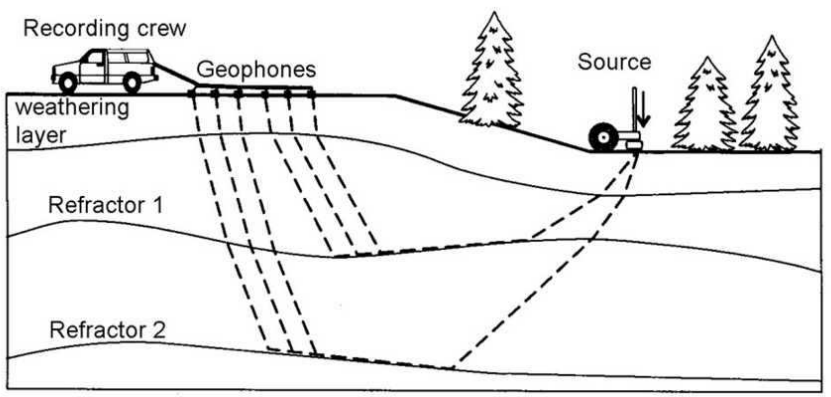

Fig. 2. Seismic method: case refraction seismic method.

Geophysical resistivity techniques are based on the response of the earth to the flow of electrical current. With an electrical current passed through the ground and two potential electrodes to record the resulting potential difference between them, we can obtain a direct measure of the electrical impedance of the subsurface material. The resistivity of the subsurface, a material constant, is then a function of the magnitude of the current, the recorded potential difference, and the geometry of the electrode array.

Depending upon the survey geometry, the data are plotted as 1D sounding or profiling curves, or in 2-D cross-section in order to look for anomalous regions. In the shallow subsurface, the presence of water controls much of the conductivity variation. Measurement of resistivity is, in general, a measure of water saturation and connectivity of pore space. Resistivity measurements are associated with varying depths relative to the distance between the current and potential electrodes in the survey, and can be interpreted qualitatively and quantitatively in terms of a lithologic and/or geohydrologic model of the subsurface [7].

The self potential (SP) method simply measures a naturally occurring potential between electrodes on the surface or in boreholes. There are three mechanisms that generate self potentials: streaming potentials due to fluid flow, electrochemical potentials generated by concentration differences of electrolytes, and thermoelectric potentials from temperature gradients [8].

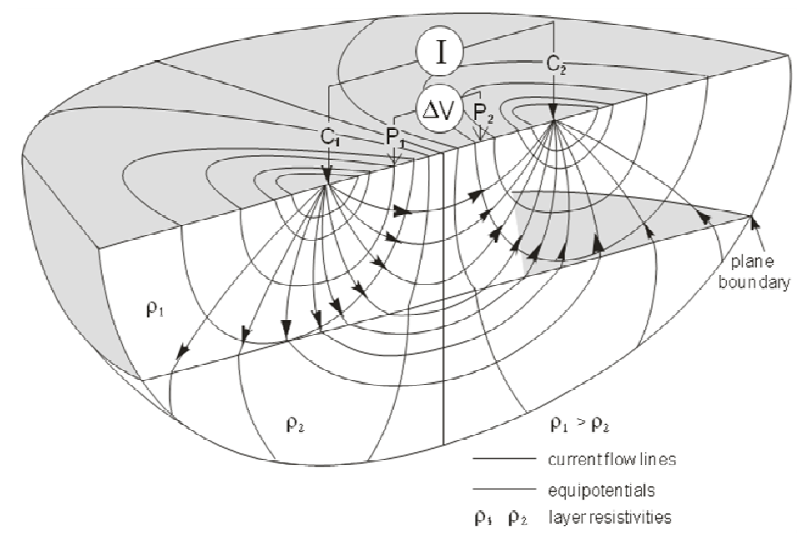

Fig. 3. Resistivity method.

Figure 4 highlights the fact that SP measurements made on the surface are the product of a current and the subsurface resistivity 
0063 structure. A resistive zone would give a positive anomaly and a conductive zone a negative anomaly.

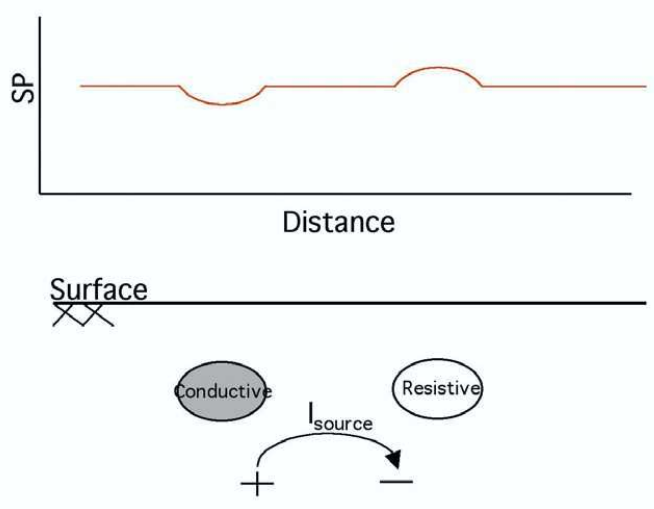

Fig. 4. Self potential method.

The gravity method is a nondestructive geophysical technique that measures differences in the earth's gravitational field at specific locations. It has found numerous applications in engineering and environmental studies including locating voids, buried stream valleys, water table levels and the determination of soil layer thickness. The success of the gravity method depends on the different earth materials having different bulk densities (mass) that produce variations in the measured gravitational field. These variations can then be interpreted by a variety of analytical and computers methods to determine the depth, geometry and density, as well as the causes of the gravity field variations [9].

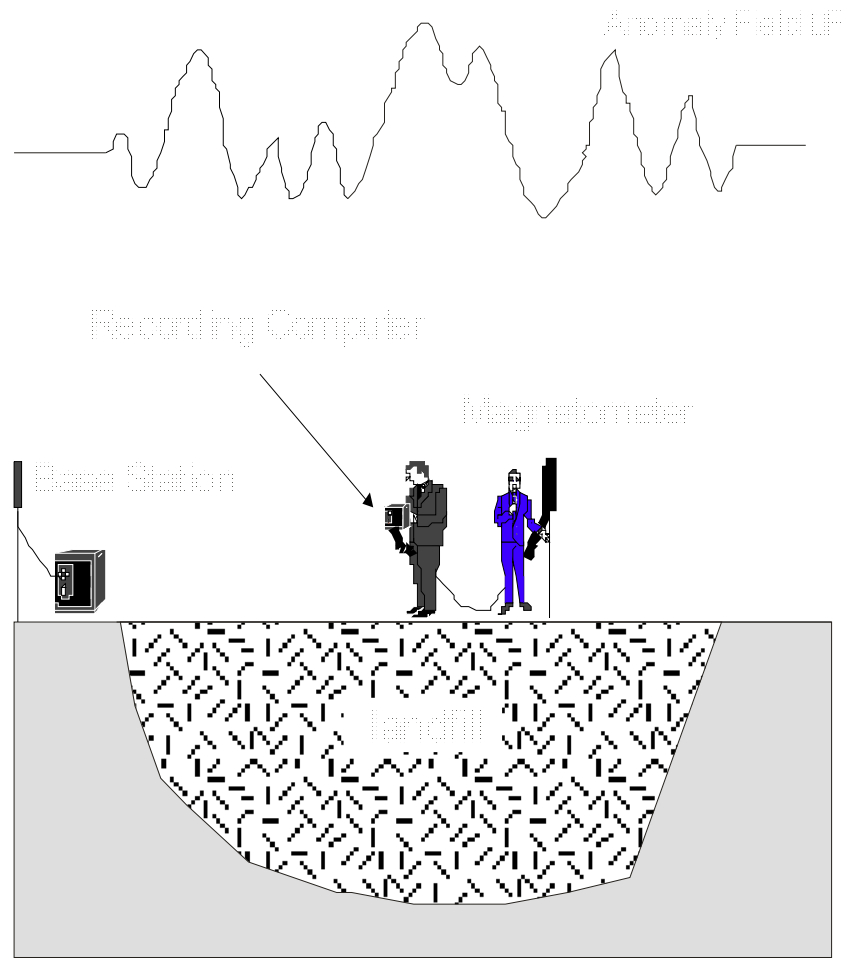

c)

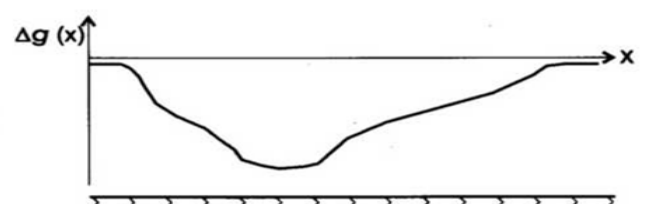

b)

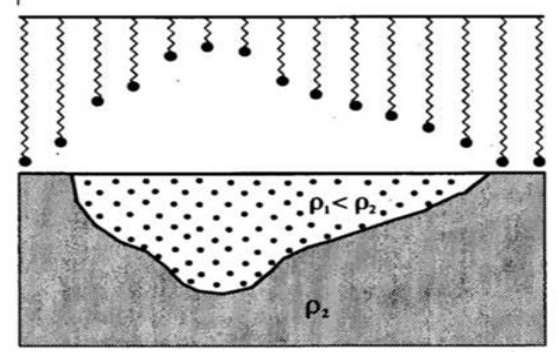

Fig. 4. Gravity method. a) The model shows a geological structure with a density $\rho_{1}$ embedded in a material with higher density $\rho_{2}$. b) A spring with a little mass due to gravity field has an extension. c) Due to the presence of the anomaly locally the gravity field is disturbed.

The magnetic method of geophysical exploration involves measurements of the direction, gradient, or intensity of the Earth's magnetic field and interpretation of variations in these quantities over the area of investigation. Magnetic surveys can be made on the land surface, from an aircraft, or from a ship. Most exploration surveys made today measure either the relative or absolute intensity of the total field or the vertical component. Measurements of magnetic intensity can be made with simple mechanical balances or with elaborate electronic instruments [2] (see fig. 5).

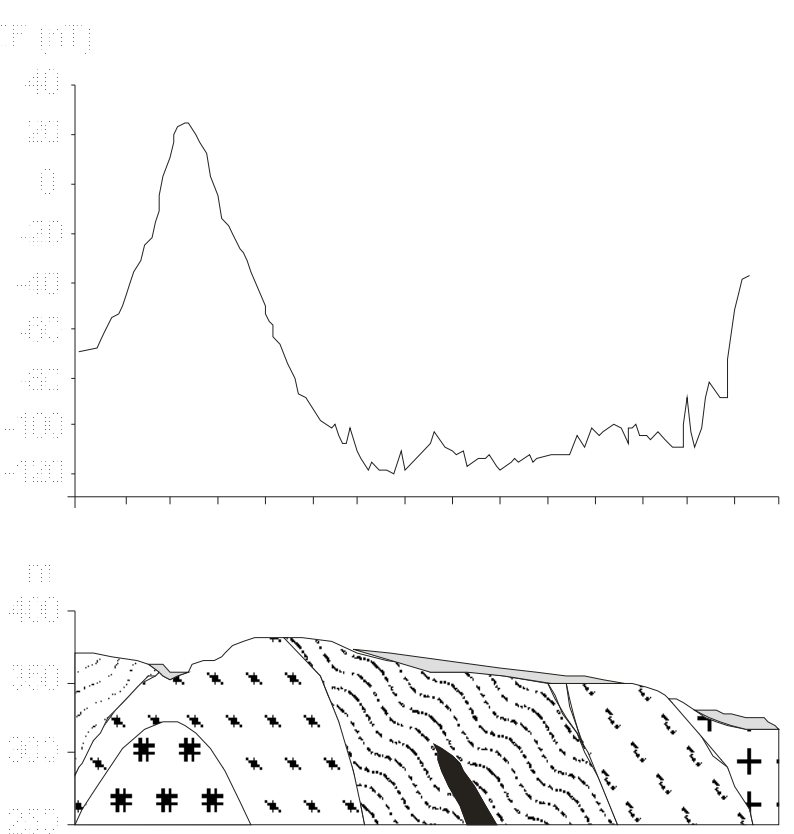

Fig. 5. Magnetic method. Typical applications of the magnetic method: search for concealed waste (left), investigation of the geology containing magnetic materials (right). 
There is a wide variety of electromagnetic (EM) survey methods. Each method involves the measurements of one or more magnetic field component induced by the subsurface by a primary field produced from a natural (transient) or artificial alternating current source. The primary field spreads out on space both above and below the ground and induces current in subsurface conductors in accordance to the laws of EM induction. These currents give a secondary EM field which distorts the primary field. The resultant field, picked up by a receiving coil, will differ from the primary field in intensity, phase and direction revealing the presence of a conductor (see Fig. 6).

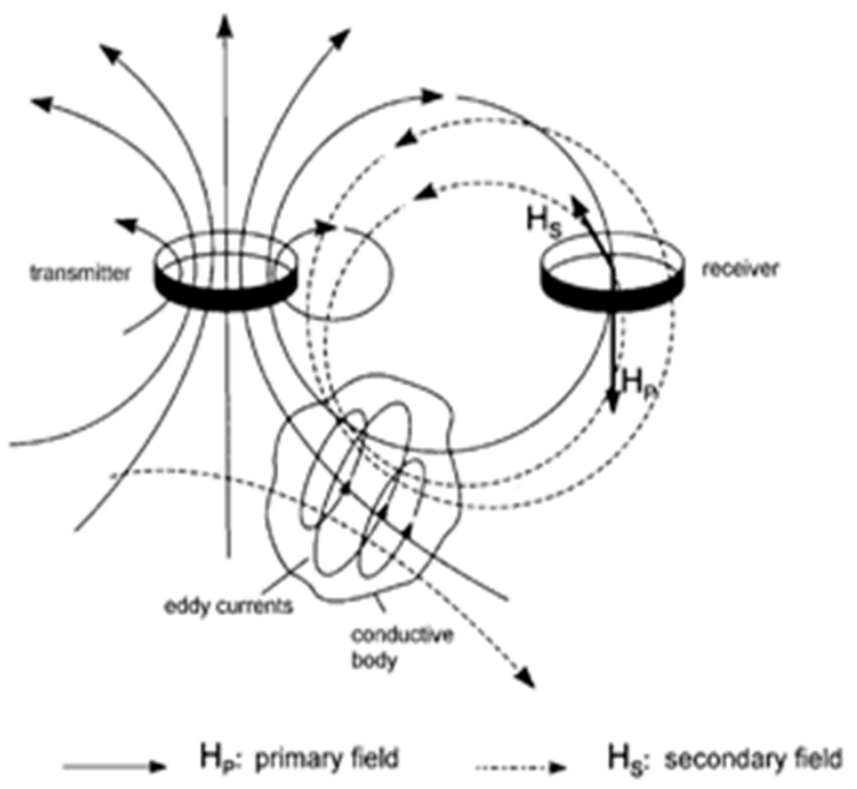

Fig. 6. Electromagnetic method.

A ground penetrating radar is a state-of-the-art geophysical measurement technique which can be applied to explore nearsurface underground structures (see Fig. 7). The measurement principle is based on the transmittance of high-frequency electromagnetic pulses into the ground. The travel time of the emitted pulses is subsequently recorded by a receiving antenna [10].

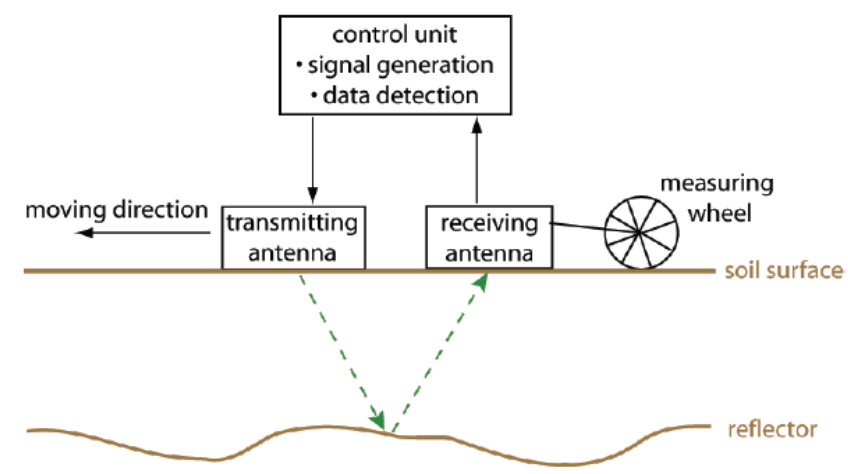

Fig. 7. Ground penetrating radar measurement principle [10].
Radioactivity measurements have played an important role in geophysics since about 1935, and they have increased in importance to the present. The most important areas of application have been in petroleum and uranium exploration. Radioactivity measurements have proved useful in geologic mapping, as well as in specialized applications such as reactor-site monitoring. The phrase "radioactivity in geophysics" could well include all techniques involving the measurement of radiation [11].

\section{GEOPHYSICS AT RTU (VASSI INSTITUTE) AND IN OTHER UNIVERSITIES}

The course of applied geophysics at the Riga Technical University (RTU) has been taught at the Institute of Energy Systems and Environment, Faculty of Energy and Power, since 2004 in collaboration with international experts from Universities and private international companies.

The course in RTU introduces different geophysical methods which are applicable solely or in combination with one another, to solve engineering and environmental problems. The mathematical fundamentals are explained shortly for each method as it is necessary for an understanding of the results. The course in RTU provides students with skills to understand which geophysical methods are more appropriate for solving specific engineering and environmental problems.

The course of applied geophysics is taught in a very large number of universities with environmental engineering/environmental science programmes, also a course included in a two year master degree in geophysics is available (e.g. ETH Zurich). In our research we included and compared eight European Universities comparing only the basic courses in applied geophysics.

Regarding specific course on applied geophysics in Latvia, together with RTU, has been found course information only for the Latvian University (LU), even if the data found are dating to the year 2007 (see Table II). The two courses are rather similar in terms of contents, the main different is related to the total amount of hours dedicated to entire course: 48 hours in RTU (4.5 ECTS) and 64 hours in LU (6.0 ECTS).

As one can see from Table 2, most of these Universities provide an applied geophysics fundament course as a part of the bachelor's programme, except ETH, DTU and POLITO, which start with the basics already in the bachelor's programme and provide advanced courses during the master's programme, including a complete master degree (ETH) and an advance field course (DTU and POLITO). KTH is including the basics of geophysical methods in a wider course called "Environmental geology". 
TABLE II

GEOPHYSICS METHOD COURSES IN SELECTED EUROPEAN UNIVERSITIES

\begin{tabular}{|c|c|c|c|c|c|c|c|c|c|}
\hline \multirow{2}{*}{ UNIVERSITY } & \multirow{2}{*}{ Nation } & \multirow{2}{*}{ MSc or Bc } & \multirow{2}{*}{ Name of couse } & \multicolumn{4}{|c|}{ Course load } & \multirow{2}{*}{ ECTS } & \multirow{2}{*}{ Exam/test } \\
\hline & & & & Total & Theory & Pract. & Ind. & & \\
\hline Riga Technical University (RTU) & LV & $\mathrm{Bc}$ & $\begin{array}{l}\text { The Waste Management in the applied } \\
\text { geophysics }\end{array}$ & 48 & 32 & 16 & - & 4,5 & Test \\
\hline Latvian University $^{1}$ & LV & $\mathrm{BC}$ & Geophysics & 64 & 40 & 24 & - & 6 & Exam \\
\hline $\begin{array}{l}\text { Swiss Federal Institute of Technology Zurich } \\
\text { (ETH) }\end{array}$ & $\mathrm{CH}$ & $\mathrm{Bc} / \mathrm{MSc}$ & $\begin{array}{l}\text { Engineering and Environmental } \\
\text { Geophysics }\end{array}$ & 42 & - & - & - & 4 & Exam \\
\hline Royal Institute of Technology (KHT) & SW & $\mathrm{BC}$ & Environmental Geology & 21 lect., 9 pract. & 21 lect. & 9 exerc. & - & 7,5 & Exam \\
\hline Technical University of Denmark (DTU) & DK & $\mathrm{BSc} / \mathrm{MSc}$ & Introduction to applied geophysic & 3 weeks & - & - & - & 5 & Exam \\
\hline University of Copenaghen (KU) & DK & $\mathrm{BC}$ & Geologically applied geophysics & 9 weeks & - & - & - & 0 & Exam \\
\hline Politechnic of Turin (POLITO) & IT & $\mathrm{BC}$ & Fundaments of geophysics & 66 & 42 & 14 & - & 7,5 & Exam * \\
\hline University of Hamburg (UH) & GER & $\mathrm{BC}$ & Applied Geophysics 1 & 4 hours/weeks & - & - & - & 5 & Test \\
\hline Bergen University (BU) & NOR & $\mathrm{BC}$ & Applied Geophysics & 60 & 30 & 30 & 135 & 6 & Exam \\
\hline Gent University (UGENT) & BEL & M.Sc. & Applied Geophysics & 60 & 30 & 30 & 135 & 10 & Exam** \\
\hline \multicolumn{4}{|l|}{${ }^{1}$ Course inofrmation year 2007} & \multicolumn{3}{|c|}{$\begin{array}{l}\text { Total = total course load } \\
\text { Theory = load of theory lectures } \\
\text { Pract. = load of practcial works } \\
\text { Ind. = individual study load required } \\
\text { ECTS = European credit points }\end{array}$} & $\begin{array}{l}* \text { oral } \\
* * \text { ora }\end{array}$ & I and $n$ & written \\
\hline
\end{tabular}

All the basic courses in applied geophysics analyzed during the study provide an introduction to the field of geophysical exploration. The common objectives are related to obtain an overview of the various methods used in the field of geophysical exploration, to obtain the practical working knowledge of selected methods, including survey planning, field operations, data processing and interpretation and to choose the adequate geophysical method depending on the targets that need to be investigated. The real field application practice, together with the processing and interpretation of field data through suitable software is not always offered as 1 learning objective (see Table III).

TABLE III

TOPICS AND TEACHING METHODS COMPARISON

\begin{tabular}{|c|c|c|c|c|c|c|c|c|c|c|}
\hline TOPICS & RTU & LU & ETH & $\mathrm{KTH}^{*}$ & DTU & KU & POLITO & UH & $\mathrm{BU} * *$ & UGENT \\
\hline Geophysics introduction & $\mathrm{x}$ & $\mathrm{X}$ & $\mathrm{x}$ & $\mathrm{x}$ & $\mathrm{x}$ & $x$ & $\mathrm{x}$ & $\mathrm{x}$ & & $x$ \\
\hline Data analysis & $x$ & $\mathrm{X}$ & $x$ & $x$ & & $\mathrm{x}$ & $x$ & $x$ & & $x$ \\
\hline Seismic methods & $\mathrm{X}$ & $x$ & $x$ & $X$ & & $X$ & $X$ & & & $X$ \\
\hline Gravity methods & $x$ & $\mathrm{X}$ & $\mathrm{x}$ & $x$ & & $\mathrm{x}$ & $x$ & $x$ & & \\
\hline Geomagnetic methods & $\mathrm{x}$ & $\mathrm{X}$ & $\mathrm{x}$ & $\mathrm{x}$ & & $x$ & $\mathrm{x}$ & $x$ & & $x$ \\
\hline Geoelectric methods & $\mathrm{x}$ & $\mathrm{X}$ & $\mathrm{x}$ & $\mathrm{x}$ & $\mathrm{x}$ & $x$ & $\mathrm{x}$ & $\mathrm{x}$ & & $\mathrm{x}$ \\
\hline Electromagnetic methods & $\mathrm{X}$ & $\mathrm{X}$ & $\mathrm{X}$ & $x$ & $x$ & $\mathrm{x}$ & $x$ & $x$ & & $x$ \\
\hline \multicolumn{11}{|l|}{\begin{tabular}{|l|} 
Radioactivity method \\
\end{tabular}} \\
\hline Other & & $\mathrm{X}$ & & $x$ & & $\mathrm{x}$ & & & $x$ & \\
\hline METHODS & RTU & & ETH & KTH* & DTU & KU & POLITO & UH & $\mathrm{BU} * *$ & UGENT \\
\hline Lecture & $x$ & $x$ & $x$ & $x$ & $x$ & $x$ & $x$ & $x$ & $x$ & $x$ \\
\hline Discussion & & & & & & & & & & $x$ \\
\hline Exercises & $x$ & $x$ & $x$ & & $x$ & & & $x$ & & $x$ \\
\hline Examples & $x$ & $\mathrm{X}$ & $x$ & $x$ & $\mathrm{X}$ & & $x$ & $x$ & & $\mathrm{x}$ \\
\hline Field practice & & & $x$ & $x$ & & & & & & $x$ \\
\hline Use of software & $\mathrm{x}$ & $\mathrm{X}$ & $\mathrm{X}$ & $\mathrm{x}$ & $\mathrm{x}$ & $\mathrm{x}$ & & & & \\
\hline Seminar & & $\mathrm{x}$ & & & & & & & & $x$ \\
\hline
\end{tabular}

* Included in the course Environmental geology

** not descrided the information for the course content

The applied geophysics course in RTU is one of shortest based on the credit points. The main differences concerning the level of detail and the amount of practical work: with an increasing of the credit points, the amount of practical work and eventually of field experience is also increasing.

\section{V.CONCLUSION: FUTURE PERSPECTIVES}

This paper has explained the judicious application of geophysical techniques to geotechnical investigations can result in significant cost savings and also in environmental benefits since the local natural conditions are not so disturbed during the survey how it is for a geotechnical survey. It has also been presented how generally even if geophysical survey costs are much lower than the drilling costs, geophysics will never entirely replace drilling because of the inherent ambiguities in the interpretation of geophysical results.

Regarding general aspects for a basic but complete course on applied geophysics, the fundamental problem is in fact to formulate a programme in which the available expertise could be employed in a course oriented towards the needs of society. 
The greatest effort in order to provide student, with the fundamental background, the essential knowledge for practicing applied geophysics should be addressed more and focused in the direction of a wider practical site experiences.

In this direction, in order to be ready for a market searching from geophysics expert companies, theoretically students should be trained in such a way that, by the end of their training, they would have the basics to understand how to start to work independently and be competitive on the market. Such skills include elementary surveying and a more thorough grasp of instrumental problems. This should be considered crucial if specialised technical personnel would have to be developed locally. Of course this vision has to face with the local situation of the University that offers the course in terms of: availability of a skilled and operating geophysics working and teaching group, availability of equipment and connection with local expert companies.

We foresee that the need for geophysics experts in Latvia in the future will increase together with the need of local experts skilled to provide solutions to engineering environmental problems (e.g. protection of soil and groundwater, safe waste disposal, geotechnical site testing, water reservoir detecting, hazard detection). In this light can be also desiderable improve the strengthening between Latvian Educational Institutions (e.g. RTU and LU) that provided this type of study course in order to improve the quality of the teaching provided.

In RTU, in order to move towards ability to educate students to execute their own practical activities in the field, an important development would be the introduction of real geophysical survey in co-operation with private companies as a teaching tool. Additionally, we can expand the course to give a larger overview of theory on the signals and the basic of geology and geomechanisc, and at the same time, propose more parctical activities based on practice on field. The section related to the use of geophysics software should be strengthened. We plan to strengthen our own expertise and focus more on field activity with a return of technical knowledge to the students favoring the possibility to cooperate more with private companies in the sector.

\section{REFERENCES}

1. Alan, G. Green and Hansruedi Maurer (ETH Zurich), Evert Slob and Kees Wapenaar (TU Delft), and Christoph Clauser and Ralf Littke (RWTH Aachen), Joint MSc programme in applied geophysics: a new concept in geophysics education, Education Feature, first break volume 25, April 2007.

2. Sharma Prem V., Environmental and engineering geophysics, Cambridge University press, 2002, p. 1.

3. http://www.geology.wisc.edu/courses/g594/

4. Vogelsang, D., Environmental Geophysics - A practical guide. Springer-Verlag, Berlin, 1995.

5. Owen, P. W., Selling geophysics: some observations on creating and marketing a geophysics program in state government, http://2006geophysics.mst.edu/hgconproceedings/2000papers/selling\%2 0geophysics $\% 20$ some $\% 20$ observations $\% 20$ on $\% 20$ creating $\% 20$ and $\% 20$ marketing.pdf

6. Hack, R., Geophysics for slope stability, Surveys in Geophysics, n. 21, 2000: pp. 423-448.

7. Cardimona, S., Electrical resistivity techniques for subsurface investigation,

http://www.dot.ca.gov/hq/esc/geotech/gg/geophysics2002/061 cardimona resistivity_overview.pdf

8. Vichabian, Y., Dale Morgan F., Massachusetts Institute of Technology, Cambridge, Massachusetts, U.S., Self potentials in cave detection, http://eps.mcgill.ca/ courses/c435/IP-and-SP/SPandcavesmodeling.pdf

9. Mickus, K., Gravity method: environmental and engineering applications, Department of Geosciences, Southwest Missouri State University, $\quad$ Springfield, http://www.dot.state.fl.us/statematerialsoffice/Geotechnical/conference/ materials/mickus.pdf

10. Ludwig, R., Gerhards, H., Klenk, P., Wollschläger, U., Buchner, J., Electromagnetic Methods in Applied Geophysics, Institute of Environmental Physics Heidelberg University, 2009.

11. J. S. Duval, Radioactivity method, Geophysics, vol. 45, no. 11, November 1980; pp. 1690-1694.

Francesco Romagnoli, researcher, $\mathrm{PhD}$ student

Institute of Energy Systems and Environment, Riga Technical University

Address: Kronvalda blv., 1 - LV1010 - Riga (Latvia)

Phone: +37128354151

e-mail: francesco.romagnoli@rtu

Dagnija Blumberga, Dr.habil.sc.ing., professor

Institute of Environment and Energy Systems, Riga Technical University

Address: Kronvalda blvd. 1, Riga, LV 1010, Latvia

Phone: 371 67089923, 37167089908 ,

Fax: 37167089908

e-mail: dagnija.blumberga@rtu.lv

Frančesko Romagnoli, Dagnija Blumberga. Lietišksās ġeofizikas studiju kurss RTU: pamats ātrai, zaḷai, lētai pazemes izpētes metodei

Ģeofizikas metodes tiek izmantotas, lai noteiktu gan pazemes telpisko modeli, gan defektu zonas, gan arī izpētītu reǵionālo pazemes ūdeṇu sistēmu, vai iegūtu litologiskos parametrus. Praktiskā geofizika paredz virsmas fizikālo parametru sadalījumu ar pētījumu palīdzību uz zemes virsmas bez augsnes veidojumu sagraušanas. Ekspertu kompānijas, kas nodrošina ǵeofizikas mērījumus, ir specifiskas. Vides ekspertiem ir nepieciešamas zināšanas šajā jautājumā. Jautājums kā valstij iegūt pieeju starptautiskajai ekspertizzei.

Specifisks g̉eofizikas studiju kursa modelis Rīgas Tehniskajā universitātē (RTU) salīdzināts ar līdzīgiem kursiem astonās Eiropas universitātēs.

Informācija par kursu ilgumu, apmācības uzdevumiem, tematiem, apmācības metodēm, kredītpunktiem un citiem parametriem apkopota rakstā. Analīzes rezultāti deva iespēju izstrādāt piedāvājumus, kā uzlabot RTU ǵeofizikas kursu.

Франческо Романьоли, Дагния Блумберга. Курс прикладной геофизики в РТУ: основы для быстрой, зелёной, дешёвой методики подземных исследований

Методы геофизики используются для определения подземной пространственной модели, дефектных зон, для исследования региональных систем подземных вод, а также для получения литологических параметров. Практическая геофизика предусматривает распределение физических параметров поверхности с помощью исследований на поверхности почвы без разрушения поверхностных образований. Экспертные компании, занимающиеся геофизическими измерениями, являются достаточно специфическими. Такого рода знания необходимы также и экспертам в области экологии. Важным вопросом является то, каким образом государство может получить доступ к международным экспертизам.

Было проведено сравнение модели специфического учебного курса Рижского технического университета (РТУ) с похожими курсами в восьми европейских университетах.

Информация о длительности курса, учебных заданиях, темах, методах обучения, кредитных пунктах и других параметрах обобщена в статье. Анализ полученных результатов дал возможность разработать предложения по улучшению курса геофизики в РТУ. 